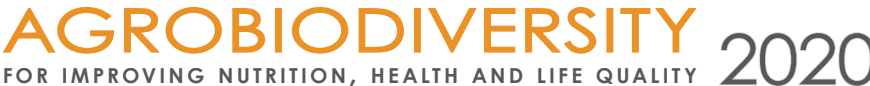

e

\section{CHEMICAL COMPOSITION OF LEAVES OF CHINESE QUINCE (PSEUDOCYDONIA SINENSIS (THOUIN) C.K. SCHNEID.)}

\section{Grygorieva Olga ${ }^{1}$, Klymenko Svitlana ${ }^{1}$, Vergun Olena ${ }^{1}$, Shelepova Olga ${ }^{2}$, Vinogradova Yulia ${ }^{2}$, Ilinska Antonina ${ }^{1}$, Horčinová Sedláčková Vladimíra ${ }^{3}$, Brindza Jan ${ }^{3}$}

\author{
${ }^{1}$ M.M. Gryshko National Botanical Garden of Ukraine, National Academy of Sciences, Kyiv, Ukraine \\ ${ }^{2}$ N.V. Tsitsin Main Botanical Garden of Russian Academy of Sciences, Moscow, Russia \\ ${ }^{3}$ Slovak University of Agriculture in Nitra, Faculty of Agrobiology and Food Resources, \\ Institute of Biodiversity Conservation and Biosafety, Nitra, Slovakia
}

Received: 19.5. 2020 Revised: 12.7.2020 Published: 20. 11. 2020

Pseudocydonia sinensis (Thouin) C.K. Schneid. less known plant species in the Ukraine conditions, but the fruits were widely used in traditional Chinese medicine for the treatment of asthma, colds, sore throat, mastitis, rheumatoid arthritis, and tuberculosis. In this study, chemical compositions of the leaves of Pseudocydonia sinensis were investigated. They contained total protein 6.66\%, ash $8.54 \%$, lipids $3.38 \%$, beta carotene $90.30 \mathrm{mg} / \mathrm{kg}$ DW. Monosaccharide analysis revealed that the neutral carbohydrate part (fructose, maltose, sucrose, and lactose) was found in low amounts only $(<0.5$ $\mathrm{g} / \mathrm{kg}$ ). The major quantitative tocopherol in leaves was $\alpha$-tocopherol $(80.73 \mathrm{mg} / \mathrm{kg} \mathrm{DW}$ ). Saturated, monounsaturated and polyunsaturated fatty acids, palmitic acid (C16:0; 53.36 g/100 g DW), oleic acid (C18:1; $12.49 \mathrm{~g} / 100 \mathrm{~g} \mathrm{DW})$ and linoleic acid (C18:2; 8.24 g/100 g DW), respectively, were found predominant. Palmitic acid makes up $57.2 \%$ of the total amount. The total amount of amino acids found in the leaves was $53.90 \mathrm{~g} / \mathrm{kg}$ DW, including total essential amino acids ( $28.60 \mathrm{~g} / \mathrm{kg} \mathrm{DW})$ and percentage of total essential amino acids (53.06\%). Glutamic acid was found of leaves to be the dominant free amino acid (6.5 g/kg DW) followed by aspartic acid (5.4 g/kg DW) and leucine (4.9 g/kg DW DW). The mineral composition of leaves of $P$. sinensis demonstrated the presence of elements in following order: $\quad \mathrm{Ca}>\mathrm{K}>\mathrm{Mg}>\mathrm{P}>\mathrm{S}>\mathrm{Fe}>\mathrm{Zn}>\mathrm{Na}>\mathrm{Mn}>\mathrm{Al}>\mathrm{Cu}>\mathrm{Ni}>\mathrm{Cr}>\mathrm{Pb}>\mathrm{Cd}>\mathrm{Hg}>\mathrm{As}>\mathrm{Se}$. Studied antioxidant parameters showed that antioxidant activity by DPPH and molybdenum reducing power was 8.76 and $289.73 \mathrm{mg} \mathrm{TE} / \mathrm{g}$, respectively. Also, the total content of polyphenols, flavonoids, and phenolic acids amounted to $65.77 \mathrm{mg} \mathrm{GAE} / \mathrm{g}, 22.47 \mathrm{mg} \mathrm{QE} / \mathrm{g}$, and $9.06 \mathrm{mg} \mathrm{CAE} / \mathrm{g}$, respectively. The obtained data represent that leaves of $P$. sisnensis contain rich mineral composition, amino, and fatty acid composition and biologically active compounds such as polyphenols that can be used in the pharmaceutical study to validate its possible medicinal application. The study of less know and neglected plant species and it's raw can increase possible use in human life beneficial plant products.

Keywords: Chinese quince, leaves, chemical compositions, antioxidant activity

*Corresponding author: Olga Grygorieva, M.M. Gryshko National Botanical Garden of Ukraine of National Academy of Sciences, Kyiv, Timiryazevska 1, 01014 Kyiv, Ukraine olgrygorieva@gmail.com 


\section{Introduction}

Interest in plants as a source of natural bioactive compounds has prompted researchers to investigate their tissue chemical composition and therapeutic potential. It is many plant species exist in the world have cultivated for food, but still less known, neglected and underutilized not full while they play important role in procuring the food security to improve health and nutrition, ecological sustainability and livelihoods (Mal, 2007; Magbagbeola et al., 2010; Dansi et al., 2012; Chivenge et al., 2015; Klymenko et al., 2017).

Chinese quince (Pseudocydonia sinensis (Thouin) C.K. Schneid.) of the family Rosaceae Juss. the only species in the genus Pseudocydonia C.K. Schneid., native to eastern Asia in China. It is closely related to the East Asian genus, Chaenomeles Lindl. (is sometimes placed in Chaenomeles as C. sinensis), and to the European genus, Cydonia Mill. (Suzuki, 1994).

Fruits of the Pseudocydonia sinensis are very fragrant, yellow edible pomes with an elliptical or ovoid shape (Mihara et al., 1987; Monka et al., 2014; Klymenko et al., 2017; Choi et al., 2018). Their fruits have a big size with a height of $98.06-124.48 \mathrm{~mm}$, an average diameter of 62.33-88.64 $\mathrm{mm}$, and an average weight in the range of 197.85-466.38 $\mathrm{g}$ (Monka et al., 2014).

The fresh fruit of Pseudocydonia sinensis are sour and hard and consumed after processing into spreads, marmalades, jams, fruit jellies, candied pulp, sweetened syrups and juices, wines, liqueurs, and use in preparing of flour products, candies (Hamauzu et al., 2006; Monka et al., 2014; Klymenko et al., 2017).

The fruit of investigated species includes organic acids, both flavonoids rutin and quercetin, procyanidins, and volatile compounds (Hamauzu et al., 2005; 2014). The main volatile compounds in Chinese quince peel are (E,E)- $\alpha$-farnesene, isobutyl octanoate, ethyl octanoate, isobutyl 7-octanoate, and hexyl hexanoate (Mihara et al., 1987). In the peel, ethyl 2-methylpropanoate, ethyl (E)-2-butenoate, ethyl 2-methyl butanoate, methional, (Z)-3hexenyl acetate, $\beta$-ionone, ethyl nonanoate, and $\gamma$-decalactone were found as the potent aroma-active compounds (Choi et al., 2018).

The fruits of the Pseudocydonia sinensis were widely used in traditional Chinese medicine for the treatment of asthma, colds, sore throat, mastitis, rheumatoid arthritis, and tuberculosis (Chung et al., 1988a; 1988b; Hamauzu et al., 2005; 2014; Mihara et al., 1987). The pharmacological studies have shown the antibacterial, antihaemolytic (Osawa et al., 1997), anti-inflammatory (Osawa et al., 1999), antipruritic (Oku et al., 2003), antioxidant (Hamauzu et al., 2005; 2007; Monka et al., 2014; Grygorieva et al., 2020), antiviral (Hamauzu et al., 2005; 2007; Sawai et al., 2008; Sawai-Kuroda et al., 2013), anti-ulcerative (Hamauzu et al., 2006), gastroprotective (Hamauzu et al., 2018), antitumor (Chun et al., 2012), and antimicrobial (Essuman et al., 2017; Kabir et al., 2015) properties of Pseudocydonia sinensis fruit.

To the best of our knowledge, there is no previously reported study of the phytochemical characteristics of Pseudocydonia sinensis leaves and scientific information still not enough. Therefore, this work was carried out to determine the chemical composition of leaves of less known species Pseudocydonia sinensis to assess the possibility of using this species in the future. 


\section{Materiall and methodology}

\section{Biological material}

Pseudocydonia sinensis (Figure 1) leaves were collected in the July 2018 from trees growing in an M.M. Gryshko National Botanical Garden (Kyiv, Ukraine). The concentration of bioactive compounds detected in the dry material.

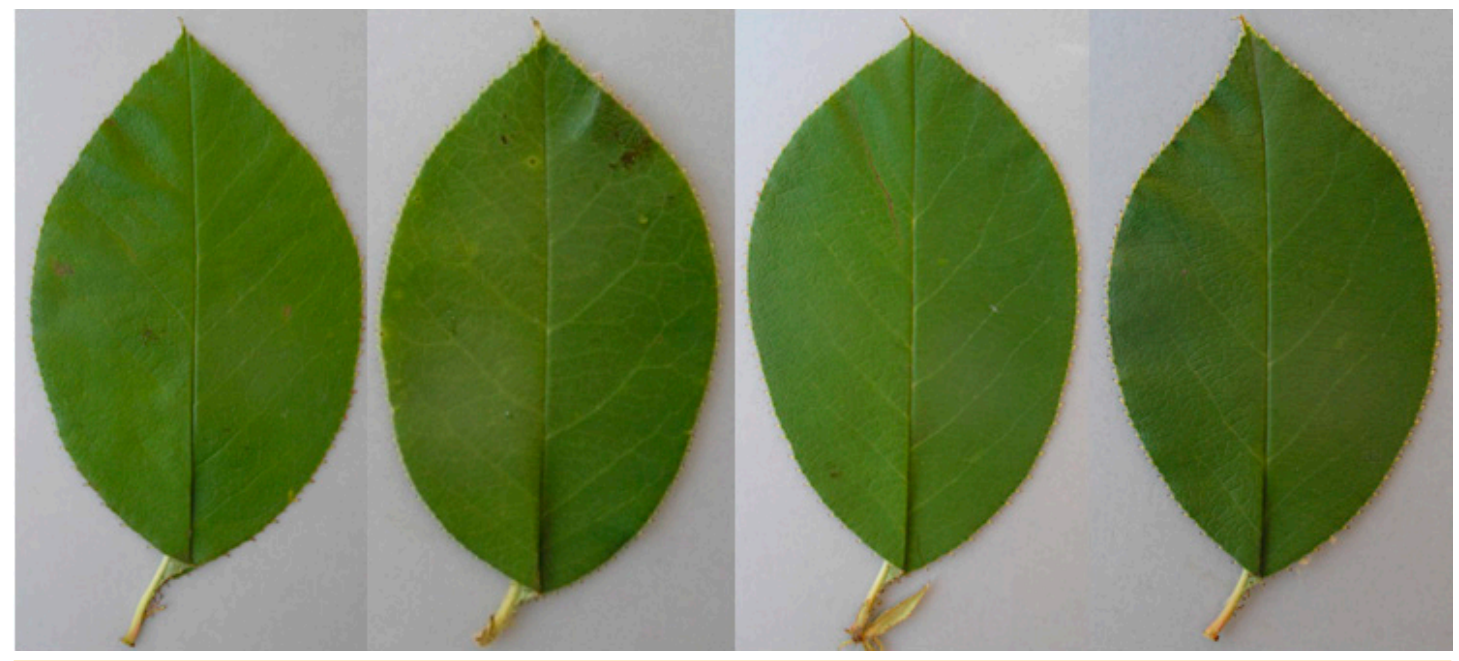

Figure 1 Leaves Pseudocydonia sinensis C.K. Schneid.

\section{Chemicals}

All the chemicals used were of analytical grade and were purchased from Sigma-Aldrich (Steinheim, Germany), Merck (Darmstadt, Germany) and CentralChem (Slovakia).

\section{Phytochemical analyses}

\section{Determination of dry matter, ash and protein content}

Total dry matter, ash, and protein content were determined according to EN method (CSN EN 12145, 1997). Total lipid content was determined according to methods specified in ISO method (ISO 659:1998).

\section{Determination of saccharides}

For the determination of saccharides, $1 \mathrm{~g}$ of sample was extracted with $10 \mathrm{~mL}$ of extraction solution (ultrapure water and ethanol mixed in ration $4: 1$ ) in a $50 \mathrm{~mL}$ centrifugation tube placed on vertical shake table (GFL, Germany). After $1 \mathrm{~h}$ of extraction, samples were centrifuged for $4 \mathrm{~min}$ at 6,000 rpm in a centrifuge (EBA 21, Hettich, Germany); the supernatant was filtered using a filter with $0.45 \mathrm{~mm}$ pore size (Labicom, Czech Republic) and filled up to $50 \mathrm{~mL}$ in a volumetric flask with ultrapure water. An Agilent Infinity 1260 liquid chromatography (Agilent Technologies, USA) equipped with ELSD detector was used for the determination of saccharides. A Prevail Carbohydrates ES column $(250 / 4.6 \mathrm{~mm})$ was used as a stationary 
phase and acetonitrile (VWR) mixed with water in $75: 25$ volume ratio was used as the mobile phase.

\section{Determination of carotenoid}

Total carotenoid content expressed as beta-carotene was analyzed at a wavelength of $445 \mathrm{~nm}$ spectrophotometrically (VIS spectrophotometer UV Jenway Model 6405 UV/VIS). Sample ( $1 \mathrm{~g}$ ) was disrupted with sea sand and extracted with acetone until complete discoloration. Petroleum-ether was added and then water, in purpose to the separation of phases. After the separation, the petroleum ether-carotenoid phase was obtained and the absorbance was measured (ČSN 560053, 1986).

\section{Determination of mineral contents}

Sample for elemental analysis was prepared using the wet ashing method in a microwave oven (Milestone 1200, Milestone, Italy). Total of $0.25 \mathrm{~g}$ sample matrix was decomposed in a mixture of nitric acid (6 mL) (Analytika Praha spol. s.r.o., Czech Republic) and hydrochloric acid (2 mL) (Analytika Praha spol. s.r.o., Czech Republic). After the decomposition sample was filtered using a filter with $0.45 \mathrm{~mm}$ pore size and filled up to $25 \mathrm{~mL}$ in a volumetric flask with ultrapure water. Elemental analysis was performed using ICP-OES (Ultima 2, Horiba Scientific, France) according to the procedure described by Divis et al. (2015).

\section{Determination of amino acids}

Amino acids were determined by ion-exchange liquid chromatography (Model AAA-400 amino acid analyzer, Ingos, Czech Republic) using post-column derivatization with ninhydrin and a VIS detector. A glass column (inner diameter $3.7 \mathrm{~mm}$, length $350 \mathrm{~mm}$ ) was filled manually with a strong cation exchanger in the LG ANB sodium cycle (Laboratory of Spolchemie) with average particles size $12 \mu \mathrm{M}$ and $8 \%$ porosity. The column was tempered within the range of 35 to $95{ }^{\circ} \mathrm{C}$. The elution of the studied amino acids took place at a column temperature set to $74^{\circ} \mathrm{C}$. A double-channel VIS detector with the inner cell volume of $5 \mu \mathrm{L}$ was set to two wavelengths: 440 and $570 \mathrm{~nm}$. A solution of ninhydrin (Ingos, Czech Republic) was prepared in $75 \% \mathrm{v} / \mathrm{v}$ methyl cellosolve (Ingos, Czech Republic) and in 2\% v/v 4 M acetic buffer (pH 5.5). Tin chloride $(\mathrm{SnCl} 2)$ was used as a reducing agent. The prepared solution of ninhydrin was stored in an inert atmosphere (N2) in darkness at $4{ }^{\circ} \mathrm{C}$. The flow rate was $0.25 \mathrm{~mL} / \mathrm{min}$. and the reactor temperature was $120^{\circ} \mathrm{C}$.

\section{Determination of total polyphenol, flavonoid, and phenolic acid content}

The total polyphenol content (TPC) was measured by the method of Singleton and Rossi (1965) using the Folin-Ciocalteu reagent. A quantity of $0.1 \mathrm{~mL}$ of each sample was mixed with $0.1 \mathrm{~mL}$ of the Folin-Ciocalteu reagent, $1 \mathrm{~mL}$ of $20 \%$ (w/v) sodium carbonate, and $8.8 \mathrm{~mL}$ of distilled water. After $30 \mathrm{~min}$ in darkness, the absorbance at $700 \mathrm{~nm}$ was measured with the spectrophotometer Jenway (6405 UV/Vis, England). Gallic acid (25-300 mg/L; $R^{2}=0.998$ ) was used as the standard. The results were expressed in $\mathrm{mg} / \mathrm{g} \mathrm{DM}$ gallic acid equivalent.

The total flavonoid content (TFC) was determined by the modified method described by Shafii et al. (2017). An aliquot of $0.5 \mathrm{~mL}$ of the sample was mixed with $0.1 \mathrm{~mL}$ of $10 \%(\mathrm{w} / \mathrm{v}$ ) 
ethanolic solution of aluminum chloride, $0.1 \mathrm{~mL}$ of $1 \mathrm{M}$ potassium acetate and $4.3 \mathrm{~mL}$ of distilled water. After $30 \mathrm{~min}$ in darkness, the absorbance at $415 \mathrm{~nm}$ was measured using the spectrophotometer Jenway (6405 UV/Vis, England). Quercetin $\left(1-400 \mathrm{mg} / \mathrm{L} ; R^{2}=0.9977\right)$ was used as the standard. The results were expressed in $\mathrm{mg} / \mathrm{g}$ DM quercetin equivalent.

Total phenolic acid (TPA) content was determined using the method of Farmakopea Polska (1999). A $0.5 \mathrm{~mL}$ of sample extract was mixed with $0.5 \mathrm{~mL}$ of $0.5 \mathrm{M}$ hydrochloric acid, $0.5 \mathrm{~mL}$ Arnova reagent $\left(10 \% \mathrm{NaNO}_{2}+10 \% \mathrm{Na}_{2} \mathrm{MoO}_{4}\right), 0.5 \mathrm{~mL}$ of $1 \mathrm{M}$ sodium hydroxide $(\mathrm{w} / \mathrm{v})$ and $0.5 \mathrm{~mL}$ of water. Absorbance at $490 \mathrm{~nm}$ was measured using the spectrophotometer Jenway (6405 UV/Vis, England). Caffeic acid $\left(1-200 \mathrm{mg} / \mathrm{L}, R^{2}=0.999\right)$ was used as a standard and the results were expressed in $\mathrm{mg} / \mathrm{g}$ DM caffeic acid equivalents.

\section{Determination of antioxidant activity}

\section{Free radical scavenging activity}

Free radical scavenging activity of samples was measured using the 2.2-diphenyl-1picrylhydrazyl (DPPH) (Sanches-Moreno et al., 1998). An amount of $0.4 \mathrm{~mL}$ of the sample was mixed with $3.6 \mathrm{~mL}$ of DPPH solution $(0.025 \mathrm{~g}$ DPPH in $100 \mathrm{~mL}$ methanol). The absorbance of the reaction mixture was determined with the spectrophotometer Jenway (6405 UV/ Vis, England) at $515 \mathrm{~nm}$. Trolox (6-hydroxy-2.5.7.8-tetramethylchroman-2-carboxylic acid) $\left(10-100 \mathrm{mg} / \mathrm{L} ; R^{2}=0.989\right)$ was used as the standard and the results were expressed in $\mathrm{mg} / \mathrm{g}$ DM Trolox equivalents.

\section{Molybdenum reducing antioxidant power}

Molybdenum reducing (MRP) antioxidant power of samples was determined by the method of Prieto et al.(1999) with slight modifications. The mixture of the sample (1 mL), monopotassium phosphate $(2.8 \mathrm{~mL}, 0.1 \mathrm{M})$, sulfuric acid $(6 \mathrm{~mL}, 1 \mathrm{M})$, ammonium heptamolybdate $(0.4 \mathrm{~mL}$, $0.1 \mathrm{M})$ and distilled water $(0.8 \mathrm{~mL})$ was incubated at $90^{\circ} \mathrm{C}$ for $120 \mathrm{~min}$, then rapidly cooled. The absorbance at $700 \mathrm{~nm}$ was detected with the spectrophotometer Jenway (6405 UV/Vis, England). Trolox $\left(10-1,000 \mathrm{mg} / \mathrm{L} ; R^{2}=0.998\right)$ was used as the standard and the results were expressed in $\mathrm{mg} / \mathrm{g}$ DMTrolox equivalent.

\section{Statistic analysis}

Basic statistical analyses were performed using PAST 2.17. Data were analyzed with ANOVA test and differences between means compared through the Tukey-Kramer test $(p<0.05)$. The variability of all these parameters was evaluated using descriptive statistics.

\section{Results and discussion}

Biochemical study of fruit plants, basically, relates to the composition of fruits and few only highlight the accumulation of biochemical compounds in the leaves. But, evidently, that leaves of fruit plants also can be a useful source of nutrients with beneficial biological activities.

Chemical analyses of Pseudocydonia sinensis leaves revealed the presence of protein (6.66 wt/ wt\%), lipids (3.38 wt/wt\%) and inorganic material (8.54 wt/wt\%) (Table 1). 
Grygorieva, O., Klymenko, S., Vergun, O., Shelepova, O., Vinogradova, Y., Ilinska, A., Horčinová Sedláčková, V., Brindza, J.

Agr.bio.div. Impr. Nut., Health Life Qual., 2020, 78-93

Table 1 The contents of some phytochemical compounds of Pseudocydonia sinensis C.K. Schneid.

\begin{tabular}{|c|c|c|c|}
\hline Components & $\bar{x} \pm S_{\mathrm{x}}^{-}$ & Components & $\bar{x} \pm S_{\mathrm{x}}^{-}$ \\
\hline Total dry matter (\%) & $92.66 \pm 3.05$ & $\begin{array}{l}\text { Polyunsaturated fatty acids } \\
\text { (g/100 g oil) }\end{array}$ & $13.40 \pm 0.11$ \\
\hline Total content of protein (\%) & $6.66 \pm 0.14$ & Fructose $(\mathrm{g} / \mathrm{kg})$ & $<0.5$ \\
\hline Total content of ash (\%) & $8.54 \pm 0.31$ & Maltose (g/kg) & $<0.5$ \\
\hline Total content of lipids (\%) & $3.38 \pm 0.12$ & Sucrose $(\mathrm{g} / \mathrm{kg})$ & $<0.5$ \\
\hline Beta carotene (mg/kg) & $90.30 \pm 1.09$ & Lactose (g/kg) & $<0.5$ \\
\hline $\begin{array}{l}\text { Saturated fatty acids } \\
\text { (g/100 g oil) }\end{array}$ & $70.0 \pm 0.56$ & $\begin{array}{l}\text { Vitamin A (retinyl acetate) } \\
(\mathrm{mg} / \mathrm{kg})\end{array}$ & $<0.1$ \\
\hline $\begin{array}{l}\text { Monounsaturated fatty acids } \\
\text { (g/100 g oil) }\end{array}$ & $12.95 \pm 0.16$ & $\begin{array}{l}\text { Vitamin E ( } \alpha \text {-tocopherol) } \\
(\mathrm{mg} / \mathrm{kg})\end{array}$ & $80.73 \pm 2.12$ \\
\hline
\end{tabular}

Note: $\bar{x}$ - arithmetic mean; $S_{x}^{-}$-standard error of the mean.

Monosaccharide analysis revealed that the neutral carbohydrate part (fructose, maltose, sucrose, and lactose) was found in low amounts only $(<0.5 \mathrm{~g} / \mathrm{kg})$. Monosaccharides are primary products of photosynthesis. They are involved in nearly all fundamental processes within plant metabolism, including synthesis of organic and amino acids, polyphenols, pigments and aroma compounds (Halford et al., 2011). It is important to underline that leaves with increased monosaccharide content were found in plants when grown under stressful factors (Wind et al., 2010). Therefore, a lower level of sugars in the leaves indicates optimal environmental conditions for plant growth.

It should be noted that the main attention of researchers is aimed at studying the composition of monosaccharides and polysaccharides of fruits and seeds of Chaenomeles species. Thus, the polysaccharide fraction from the seeds of Chaenomeles sinensis and Chaenomeles speciosa consists of arabinose, glucose, xylose, galacturonic acid and glucuronic acid (Wang et al., 2018; Deng et al., 2020). Hypoglycemic analyzes showed that polysaccharides have good activity in inhibiting $\alpha$-amylase and $\alpha$-glucosidase. Therefore, a polysaccharide from the Chaenomeles species can be used as a potential natural source to slow down the effects of postprandial hyperglycemia. Also, polysaccharides and monosaccharides from these plants can be used in the food and pharmaceutical industries.

Pseudocydonia sinensis contains beta carotene $(90.30 \mathrm{mg} / \mathrm{kg})$. Carotenoids are among the most common natural pigments, and with $\beta$-carotene as the most prominent. They are pigments that play a major role in the protection of plants against photooxidative processes. Carotenoids are efficient antioxidants scavenging singlet molecular oxygen and peroxyl radicals. They interact synergistically with other antioxidants (Stahl and Sies, 2003).

The major quantitative tocopherol in Pseudocydonia sinensis leaves was $\alpha$-tocopherol $(80.73$ $\mathrm{mg} / \mathrm{kg}$ DWP). Four tocopherols and tocotrienols are collectively referred to as vitamin E. The reactivity with organic peroxyl radicals accounts for their antioxidant activity and is believed to be their major biochemical function (Shahidi and Ambigaipalan, 2015). These reactions are 
the basis that vitamin E functions as an antioxidant, protecting tissue lipids from free radical attack.

The oil contents were $3.4 \%$ dry weight plant material (Table 1 ). It is reasonable because the majority of botanical materials (leaves) contain low amounts of lipids. The fatty acids composition was comprised of saturated fatty, monounsaturated, and polyunsaturated fatty acids (70.0; 12.95 and $13.40 \mathrm{~g} / 100 \mathrm{~g}$ oil, respectively).

The lipophilic fraction contains of 20 fatty acids (Figure 2); five acids (palmitic acid C-16:0 in quantity $53.4 \mathrm{~g} / 100 \mathrm{~g}$; oleic acid C-18:1 in quantity $12.5 \mathrm{~g} / 100 \mathrm{~g}$; linoleic acid C-18:2 in quantity $8.2 \mathrm{~g} / 100 \mathrm{~g}$; stearic acid, C-18:0 in quantity $8.0 \mathrm{~g} / 100 \mathrm{~g}$; linolenic acid, C-18:3 in quantity $8.0 \mathrm{~g} / 100 \mathrm{~g}$ ) are dominated. Of these acids, amounted to $87.3 \%$ of the total (Figure 2). P. sinensis fatty acid profiles showed the presence of high amounts of palmitic acid (53.4\%) (Figure 2). Palmitic acid is dominated in fatty acid profiles of leaves of many species such as Lamiaceae species (27.7-60.0\%) (Cacan et al., 2018; Kilic, 2018); Cassia tora (L.) Roxb. (18.6-38.7\%) (Shukla et al., 2018); Nicotiana species (13-18\%) (Koiwai et al., 1983); Cistus ladanifer L. (13.6-17.5\%) (Jerónimo et al., 2020). The second quantitatively major compound was oleic acid (12.5\%). There are literature reports of insecticidal activity of oleic acid against Aedesae gyptii larvae (Kumar et al., 2009).

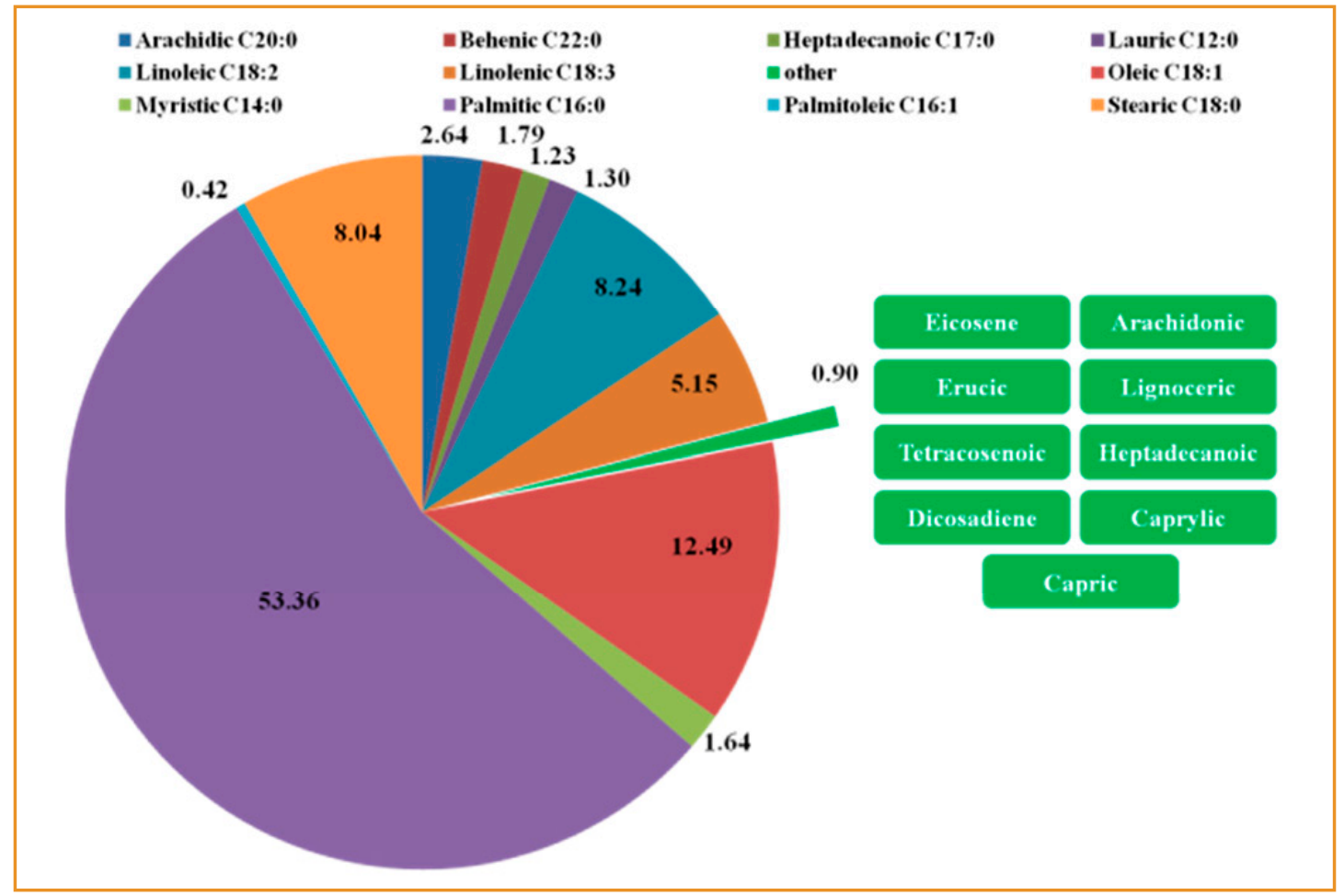

Figure 2 Fatty acid composition from leaves of Pseudocydonia sinensis C.K. Schneid. (g/100 g oil). Minor components $(<0.1)$

Eicosene C20:1; Arachidonic C20:4; Erucic C22:1; Lignoceric C24:0; Tetracosenoic C24:1; Heptadecanoic C17:1; Dicosadiene C22:2; Caprylic C8:0; Capric C10:0 are in the right column, their total amount is 0.9 $\mathrm{g} / 100 \mathrm{~g}$ oil 
According to the literature, Pseudocydonia sinensis fruit was rich in oleanolic acid and ursolic acid (Zhou et al., 2020). In addition, from the twigs of Pseudocydonia sinensis isolated five new oxylipins of chaenomic acid (Kim et al., 2014).

Lipids consisted of fatty acids, classified on saturated, monounsaturated, and polyunsaturated fatty acids (Mišurcová et al., 2011). Fatty acids play an important role as nutritious substances and metabolites in living organisms (Cakir, 2004). Many fatty acids are known to have antibacterial and antifungal properties (McGaw et al., 2002; Seidel and Taylor, 2004) and also have an important impact on human health, particularly in the prevention of cardiovascular disease, coronary heart disease, cancer, hypertension, diabetes type two, renal diseases, rheumatoid arthritis, ulcerative colitis, and Crohn's disease (De Caterina et al., 2000; Abedi and Sahari, 2014).

Fatty acids are involved in the formation of plant adaptive capacity to abiotic stresses: extreme positive and negative temperatures, lack of moisture causes a change in the composition of fatty acids (Gigon et al., 2004; Liu and Huang, 2004; Zhon get al., 2011; Li et al., 2017).

Amino acid analysis has shown that the studied Pseudocydonia sinensis leaves contained 18 amino acids (10 essential and 8 non-essential) (Figure 3).

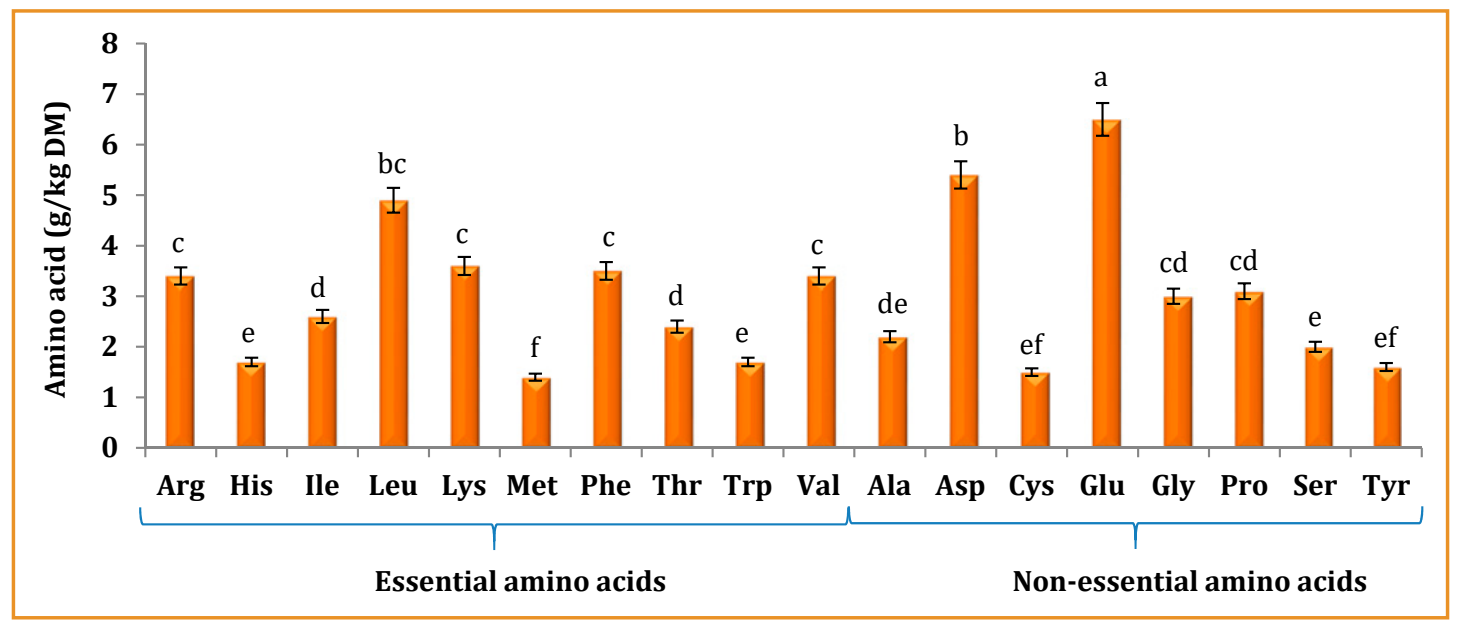

Figure 3 Amino acid composition of Pseudocydonia sinensis C.K. Schneid. leaves, g/kg DM (different superscripts in each column indicate the significant differences in the mean at $p<0.05$ )

Total amount of amino acids found in the leaves was $53.90 \mathrm{~g} / \mathrm{kg} \mathrm{DM}$, including total essential amino acids ( $28.60 \mathrm{~g} / \mathrm{kg} \mathrm{DM}$ ) and percentage of total essential amino acids (53.06\%). Glutamic acid was found of leaves to be the dominant free amino acid $(6.5 \mathrm{~g} / \mathrm{kg})$ followed by aspartic acid $(5.4 \mathrm{~g} / \mathrm{kg})$ and leucine $(4.9 \mathrm{~g} / \mathrm{kg})$.

One important factor for the formation of active constituents in plants is the trace elements because they are known to play an important role in plant metabolism and active constituents of medicinal plants are metabolic products of plant cells. In fact, the chemical constituents present in plants are responsible for their medicinal as well as toxic properties which 
include vegetable bases comprising of alkaloids and amines, glycosides, essential oils responsible for their characteristic odour, toxic substances known as toxalbumin, resins, and antibiotics. Whereby the trace elements play a very important role in the formation of these compounds.

In addition, leaf analysis for mineral elements is an important guide to sustainable plant nutrition. The mineral composition of plants is influenced by factors such as growing conditions (climate, soil) and the phase of plant development (phenophase) (Penauelas et al., 2001; Erdal et al., 2006; Lipa, 2013; Yildirim et al., 2015).

The results of the elemental analysis of Pseudocydonia sinensis leaves are summarized in Table 2.

Table 2 Mineral composition of Pseudocydonia sinensis C.K. Schneid. leaves (mg/kg)

\begin{tabular}{lclclc}
\hline Components & $\overline{\boldsymbol{x}} \pm S_{\boldsymbol{x}}$ & Components & $\overline{\boldsymbol{x}} \pm S_{\boldsymbol{X}}$ & Components & $\overline{\boldsymbol{x}} \pm S_{\bar{x}}$ \\
\hline $\mathbf{P}$ & $1,776 \pm 117$ & $\mathbf{M g}$ & $3,113 \pm 218$ & $\mathbf{S e}$ & $<0.2$ \\
$\mathbf{K}$ & $10,628 \pm 321$ & $\mathbf{N a}$ & $13.0 \pm 0.7$ & $\mathbf{A s}$ & $<0.3$ \\
$\mathbf{C a}$ & $24,304 \pm 450$ & $\mathbf{A l}$ & $8.9 \pm 1.4$ & $\mathbf{C d}$ & $0.051 \pm 0.003$ \\
$\mathbf{S}$ & $1,335 \pm 98$ & $\mathbf{C r}$ & $0.20 \pm 0.08$ & $\mathbf{N i}$ & $1.37 \pm 0.02$ \\
$\mathbf{F e}$ & $56.0 \pm 1.6$ & $\mathbf{C u}$ & $6.0 \pm 0.7$ & $\mathbf{H g}$ & $0.024 \pm 0.005$ \\
$\mathbf{M n}$ & $9.8 \pm 0.8$ & $\mathbf{Z n}$ & $32.0 \pm 1.5$ & $\mathbf{P b}$ & $0.100 \pm 0.003$ \\
\hline
\end{tabular}

Note: $\bar{x}$ - arithmetic mean; $S_{x}^{-}$- standard error of the mean.

Concentration of various elements of leaves decreases in the order: $\mathrm{Ca}>\mathrm{K}>\mathrm{Mg}>\mathrm{P}>\mathrm{S}>\mathrm{Fe}>\mathrm{Zn}>\mathrm{Na}>\mathrm{Mn}>\mathrm{Al}>\mathrm{Cu}>\mathrm{Ni}>\mathrm{Cr}>\mathrm{Pb}>\mathrm{Cd}>\mathrm{Hg}>\mathrm{As}>\mathrm{Se}$. Among the various elements $\mathrm{As}$, Se, Cd, $\mathrm{Hg}$ are found to be present at the trace level. Fe, $\mathrm{Zn}, \mathrm{Mn}, \mathrm{Na}, \mathrm{Al}, \mathrm{Ni}$, and $\mathrm{Cu}$ are at the minor level, and $\mathrm{Ca}, \mathrm{K}, \mathrm{Mg}$, $\mathrm{P}$, and $\mathrm{S}$ are at the major levels. This result confirmed by the data Lewko et al. (2004) and showed that the leaves of quince (Cydonia oblonga) contained a large amount of calcium. Calcium is an essential mineral for human health, participating in the biological functions of several tissues (musculoskeletal, nervous and cardiac system, bones and teeth, and parathyroid gland). In addition, Ca can act as a cofactor in enzyme reactions (fatty acid oxidation, mitochondrial carrier for ATP, etc.) and it is involved in the maintenance of the mineral homeostasis and physiological performance in general (Theobald, 2005; Huskisson et al., 2007; Morgan, 2008; Williams, 2008).

Based on a large amount of scientific data proving the beneficial effect of phenolic content in humans, it is appropriate to perform estimation of these compounds content of leaves extracts of Pseudocydonia sinensis.

The amount of total phenolic acid, flavonoids, and polyphenols content was $9.06 \mathrm{mg} \mathrm{CAE} / \mathrm{g}$ DW, $22.47 \mathrm{mg} \mathrm{QE} / \mathrm{g} \mathrm{DW}$, and $65.73 \mathrm{mg} \mathrm{GAE} / \mathrm{g}$ DW, respectively (Figure 4). 


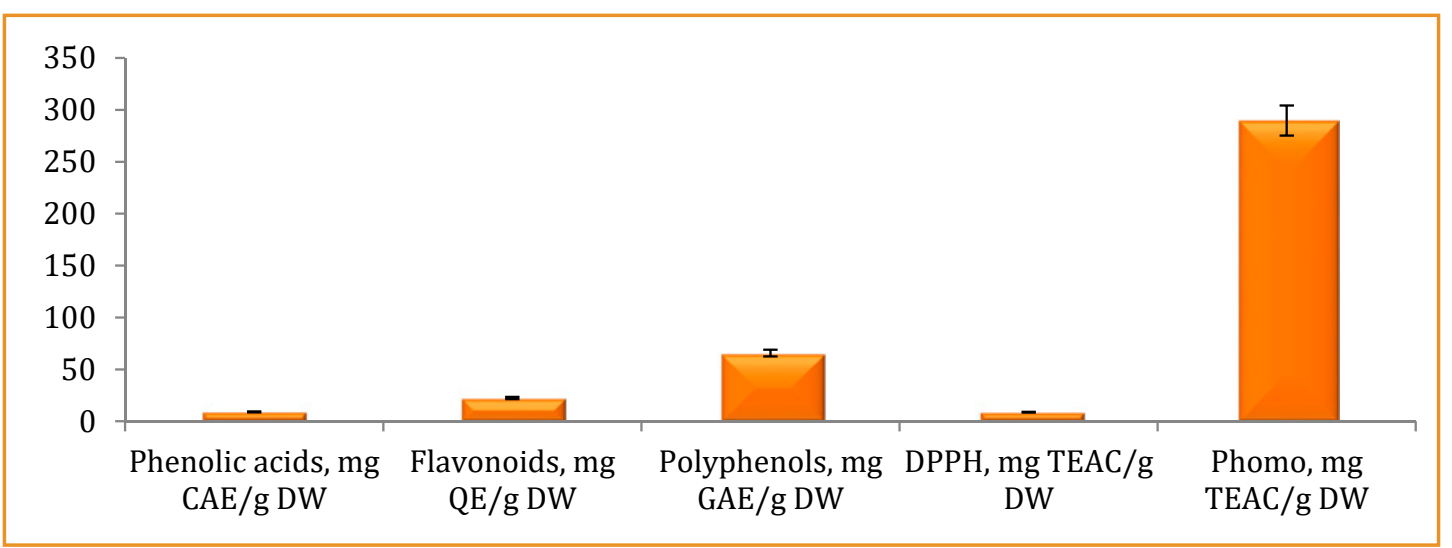

Figure 4 Parameters of antioxidant activity of Pseudocydonia sinensis C.K. Schneid. leaves

The leaves of crops and wild plants are a valuable source of antioxidant substances, especially polyphenols. According to published data, the total phenol content for the leaves of Mangifera indica L. was $65 \mathrm{mg} / \mathrm{g}$, for Anacardium occidentale L. $58.57 \mathrm{mg} / \mathrm{g}$, for Cymbopogon citratus (DC.) Stapf $28.30 \mathrm{mg} / \mathrm{g}$, for Carica papaya L. $21.80 \mathrm{mg} / \mathrm{g}$ (Iyawe and Azih, 2011), for Euphorbia spp. 19.10-20.30 mg/g (Gapuz and Besagas, 2018) and for Azadirachta indica Juss. $14.43 \mathrm{mg} / \mathrm{g}$ (Iyawe and Azih, 2011). Thi and Hwang (2014) found that the total polyphenol content of Aronia mitschurinii ranged from 139.3 to $250.8 \mathrm{mg}$ GAE/g DW. The result of another study submitted by Shahin et al. (2019), related to Aronia melanocarpa, demonstrated that the total polyphenol content in the dried leaves was $765.63 \mathrm{mg}$ GAE/g. According to Męczarska et al. (2017), Amelanchier alnifolia leaves showed a total polyphenol content of $185.23 \mathrm{mg} \mathrm{GAE} / \mathrm{g}$ DW. As reported by Barreira et al. (2010), the total flavonoid content of Castanea sativa Mill. 73.31-90.39 mg/g, for data of Stankovic et al. (2014) Cornus mas L. leaves had a total flavonoid content of $22.18 \mathrm{mg} / \mathrm{g}$, according to Al-Saeedi et al. (2016) for Ziziphus jujuba Mill. methanol extracts were $90.28 \mathrm{mg} / \mathrm{g}$.

The information about the characterization of Pseudocydonia sinensis leaf extract is limited. Zhou et al. (2020) using HPLC reported the phenolic profile of leaves and found 5-compounds. Phthalic acid, di(2.3-dimethylphenyl) ester (3.693\%), heptasiloxane, hexadecamethyl (25.425\%) and neophytadiene (25.309\%) are major compound in the leaves.

Most research on Cydonia oblonga leaf characterization is form Portugal (Oliveria et al., 2007). The total phenolic content of $C$. oblonga leaves was very high, varying from 4.9 to $16.5 \mathrm{~g} / \mathrm{kg}$ dry matter (mean value of $10.3 \mathrm{~g} / \mathrm{kg}$ dry matter). In the phenolic profile of Portuguese quince leaves were found 9 compounds. The 5-0-caffeoylquinic acid was the major compound (36.2\%), followed by quercetin-3-0-rutinoside (21.1\%) and kaempferol-3-0-rutinoside (12.5\%). The leaves of Tunisian quince variety "Commune" have 9-phenolic acids and flavonoids (Benzarti et al., 2018). Among these polyphenols, 6-were identified, one as caffeoylquinic acid (4-0-caffeoylquinic acid), two as quercetin heterosides (quercetin-3-0-rutinoside and quercetin-3-0-galactoside), and three as kaempferol heterosides (kaempferol-3-0-rutinoside, kaempferol-3-0-glycoside, and kaempferol-3-0-glucoside). 
The evaluation of the antioxidant activity of leaf extracts showed that Pseudocydonia sinensis leaves have reducing capacity and 2.2-diphenyl-1-picrylhydrazyl (DDPH) radical scavenging activity. Antioxidant activity by DPPH method and molybdenum reducing antioxidant power method 8.76 and $289.79 \mathrm{mg}$ TEAC/g DW, respectively (Figure 4).

Zhou et al. (2020) described Pseudocydonia sinensis leaves contain abundant bio-energy components, such as Heptasiloxane, hexadecamethyl-, which has a higher content in ethanol extracts, and the active components of medical components, such as d-alpha-tocopherol, which are contained in both solvent extracts (ethanol and acetone.) Hamauzu et al. (2006) described Chinese quince fruits and leaves comprise a hopeful natural source of bioactive compounds, namely caffeoylquinic acids and epicatechin. The antioxidant and antiproliferative activities described for this material may be indicative of application in nutritional and pharmaceutical fields, in the prevention and treatment of free radical-mediated human chronic pathologies, such as cardiovascular diseases and cancer. Leaves from Pseudocydonia sinensis can be used as an immense natural and inexpensive source of bioactive compounds with major antioxidative properties along with other mechanisms of action. By modulating various cardiovascular risk factors such as atherosclerosis, smoking, endothelial dysfunction hypertension, diabetes, and hyperhomocysteinaemia, Pseudocydonia sinensis leaf extract may have relevance in the prevention and treatment of different pathological states of ischemic inflammatory and hypertrophic heart disease.

\section{Conclusion}

As a result, this study demonstrates that leaves of Pseudocydonia sinensis rich source of useful biochemical compounds that conclude mineral components and polyphenol compounds. Among mineral compounds, the high concentrations found for calcium, potassium, magnesium, and phosphorus. Also, plant raw of Pseudocydonia sinensis leaves had potential as an antioxidant resource that can be used in further study. The findings of this study support the fact that leaves of Pseudocydonia sinensis can be used as a raw material in medical practice as well as the development and production of dietary supplements and cosmetic preparations rich in biologically active compounds.

\section{Acknowledgments}

This work was supported by the Bilateral Scholarship of the Ministry of Education, Science, Research and Sport (Slovak Republic) and Visegrad Fund. Experimental activities were realized in the laboratories of centre of excellence for the conservation and use of agrobiodiversity at the Faculty of Agrobiology and Food Resources, Slovak Agricultural University in Nitra.

\section{References}

ABEDI, E., SAHARI, M.A. 2014. Long-chain polyunsaturated fatty acid sources and evaluation of their nutritional and functional properties. In Food Science and Nutrition, vol. 2(5), p. 443-463. https:// doi.org/10.1002/fsn3.121

AL-SAEEDI, A.H., AL-GHAFRI, M.T.H., HOSSAIN, M.A. 2016. Comparative evaluation of total phenols, flavonoids content and antioxidant potential of leaf and fruit extracts of Omani Ziziphus jujuba L. 
In Pacific Science Review A: Natural Science and Engineering, vol. 18(1), p. 78-83. https://doi. org/10.1016/j.psra.2016.09.001

BARREIRA, J.C.M., FERREIRA, I.C.F.R., OLIVEIRA, M.B.P.P., PEREIRA, J.A. 2010. Antioxidant potential of chestnut (Castanea sativa L.) and almond (Prunus dulcis L.) by-products. In Food Science and Technology International, vol. 16(3), p. 209-216. http://dx.doi.org/10.1177/1082013209353983

BENZARTI, S., BELKADHI1, K., HAMDI, H. 2018. Biological activities of phenolics from leaves of Tunisian Cydonia oblonga Miller. In Allelopathy Journal, vol. 45(2), p. 229-242. https://doi.org/10.26651/ allelo.j/2018-45-2-1189

CACAN, E., KOKTEN, K., KILIC, O. 2018. Leaf fatty acid composition of some Lamiaceae taxa from Turkey. In Progress in Nutrition, vol. 20(1), p. 231-236. https://doi.org/10.23751/pn.v20i1-S.5930

CAKIR, A. 2004. Essential oil and fatty acid composition of the fruits of Hippophae rhamnoides L. (Sea Buckthorn) and Myrtus communis L. from Turkey. In Biochemical Systematics and Ecology, vol. 32(9), p. 809-816. https://doi.org/10.1016/j.bse.2003.11.010

ChIVENGE, P., MABHAUDHI, T., MODI, A.T., MAFONGOYA, P. 2015. The Potential Role of Neglected and Underutilised Crop Species as Future Crops under Water Scarce Conditions in Sub-Saharan Africa. In International Journal of Environmental Research and Public Health, vol. 12(6), p. 5685-5711. https://doi.org/10.3390/ijerph120605685

CHOI, J.Y., LEE, S.M., LEE, H.J., KIM, Y.-S. 2018. Characterization of aroma-active compounds in Chinese quince (Pseudocydonia sinensis Schneid) by aroma dilution analyses. In Food Research International, vol. 105, p. 828-835. https://doi.org/10.1016/j.foodres.2017.12.015

CHUN, J.M., NHO, K.J., LEE, A.Y., MOON, B.C., PARK, J.Y., KIM, H.K. 2012. A methanol fraction from Chaenomeles sinensis inhibits hepatocellular carcinoma growth in vitro and in vivo. In Journal of the Korean Society for Applied Biological Chemistry, vol. 55, p. 335-341. https://doi.org/10.1007/ s13765-012-1043-7

CHUNG, T.Y., CHO, D.S., SONG, J.C. 1988a. Volatile flavor components in Chinese quince fruits, Chaenomeles sinensis Koehne. In Korean Journal of Food Science and Technology, vol. 20, p. 176-187.

CHUNG, T.Y., CHO, D.S., SONG, J.C. 1988b. Nonvolatile flavor components in Chinese quince fruits, Chaenomeles sinensis Koehne. In Korean J Food Sci Technol., vol. 20(3), p. 293-302.

DANSI, A., VODOUH`E, R., AZOKPOTA, P., YEDOMONHAN, H., ASSOGBA, P, ADJATIN, A., LOKO, Y. L., DOSSOU-AMINON, I. AKPAGANA K. 2012. Diversity of the neglected and underutilized crop species of importance in Benin. In The Scientific World Journal, vol. 2012, Article ID 932947, 19 p. https://doi.org/10.1100/2012/932947

DE CATERINA, R., LIAO, J.K., LIBBY, P. 2000. Fatty acid modulation of endothelial activation. In American Journal of Clinical Nutrition, vol. 71(1), p. 213S-223S. https://doi.org/10.1093/ajcn/71.1.213S

DENG, Y., HUANG, L., ZHANG, C., XIE, P., CHENG, J., WANG, X., LIU, L. 2020. Novel polysaccharide from Chaenomeles speciosa seeds: Structural characterization, $\alpha$-amylase and $\alpha$-glucosidase inhibitory activity evaluation. In International Journal of Biological Macromolecules, vol. 153, p. 755-766. https://doi.org/10.1016/j.ijbiomac.2020.03.057

DIVIS, P., PORIZKA, J., VESPALCOVA, M., MATEJICEK, A., KAPLAN, J. 2015. Elemental composition of fruits from different black elder (Sambucus nigra L.) cultivars grown in the Czech Republic. In J. Elementol., vol. 20(3), p. 549-557. https://doi.org/10.5601/jelem.2015.20.1.758

ERDAL, I., KEPENEK, K., KIZILGÖZ, I. 2006. Effects of elemental sulphur and sulphur containing waste on the iron nutrition of strawberry plants grown in a calcareous soil. In Biological Agriculture and Horticulture, vol. 23(3), p. 263-272. https://doi.org/10.1080/01448765.2006.9755328

ESSUMAN, E.K., NAGAJYOTHI, P.C., TETTEY, C.O. 2017. Antioxidant, Ferric iron chelation and antimicrobial activities of extracts of Pseudocydonia sinensis (Chinese Quince) fruit. In Journal of Medicinal Plants Studies, vol. 5, p. 175-179.

FARMAKOPEA POLSKA. 1999. Poland: The Polish Farmaceutical Society, p. 880-881. 
GAPUZ, M.C.D., BESAGAS, R.L. 2018. Phytochemical profiles and antioxidant activities of leaf extracts of Euphorbia species. In Journal of Biodiversity and Environmental Sciences, vol. 12(4), p. 59-65.

GIGON, A., MATOS, A., LAFFRAY, D., ZUILY-FODIL, Y., PHAM-THI, A. 2004. Effect of drought stress on lipid metabolism in the leaves of Arabidopsis thaliana (Ecotype Columbia). In Ann. Bot. (Lond.), vol. 94, p. 345-351. https://doi.org/10.1093/aob/mch150

GRYGORIEVA, O., KLYMENKO, S., VERGUN, O., MŇAHONČÁKOVÁ, E., BRINDZA, J., TERENTJEVA, M., IVANIŠOVÁ, E. 2020. Evaluation of the an-tioxidant activity and phenolic content of Chinese quince (Pseudocydonia sinensis Schneid.) fruit. In Acta Sci. Pol. Technol. Aliment., vol. 19, p. 25-36. http:// dx.doi.org/10.17306/J.AFS.2020.0738

HALFORD, N.G., CURTIS, T.Y., MUTTUCUMARU, N., POSTLES, J., MOTTRAM, D.S. 2011. Sugars in crop plants. In Ann. Appl. Biol., vol. 158(1), p. 1-25. https://doi.org/10.1111/j.1744-7348.2010.00443.X

HAMAUZU, Y., INNO, T., KUME, C., IRIE, M., HIRAMATSU, K. 2006. Antioxidant and antiulcerative properties of phenolics from Chinese quince, quince, and apple fruits. In Journal of Agricultural and Food Chemistry, vol. 54(3), p. 765-772. http://dx.doi.org/10.1021/if052236y

HAMAUZU, Y., KUME, C., YASUI, H., FUJITA, T. 2007. Reddish coloration of Chinese quince (Pseudocydonia sinensis) procyanidins during heat treatment and effect on antioxidant and antiinfluenza viral activities. In Journal of Agricultural and Food Chemistry, vol. 55(4), p. 1221-126. http://dx.doi. org/10.1021/jf061836+

HAMAUZU, Y., NAKAMURA, K. 2014. Changes in plasma phenolic metabolites of rats administered different molecular-weight polyphenol fractions from Chinese Quince fruit extracts. In Journal of Food Biochemistry, vol. 38(4), p. 407-414. https://doi.org/10.1111/ifbc.12067

HAMAUZU, Y., TAKEDACHI, N., MIYASAKA, R., MAKABE, H. 2010. Heat treatment of Chinese quince polyphenols increases rat plasma levels of protocatechuic and vanillic acids. In Food Chemistry, vol. 118(3), p. 757-763. https://doi.org/10.1016/j.foodchem.2009.05.054

HAMAUZU, Y., YASUI, H., INNO, T., KUME, C., OMANYUDA, M. 2005. Phenolic profile, antioxidant property, and anti-influenza viral activity of Chinese quince (Pseudocydonia sinensis Schneid.), quince (Cydonia oblonga Mill.), and apple (Malus domestica Mill.) fruits. In Journal of Agricultural and Food Chemistry, vol. 53(4), p. 928-934. http://dx.doi.org/10.1021/jf0494635

HUSKISSON E., MAGGINI S., RUF, M. 2007. The role of vitamins and min-erals in energy metabolism and well-being. In J. Int. Med. Res., vol. 35, p. 277-289

IYAWE, H.O.T., AZIH, M.C. 2011. Total phenolic contents and lipid peroxidation potentials of some tropical antimalarial plants. In Eur J Med Plants, vol. 1, p. 33-39. http://dx.doi.org/10.9734/ EJMP/2011/171

JERÓNIMO, E., CACHUCHO, L., SOLDADO, D., GUERREIRO, O., BESSA, R.J.B., ALVES, S.P. 2020. Fatty acid content and composition of the morphological fractions of Cistus ladanifer L. and its seasonal variation. In Molecules, vol. 25(7), p. 1550. http://dx.doi.org/10.3390/molecules25071550

KABIR, F., SULTANA, S.M., HOSSEN, I., KURNIANTA, H. 2015. Antimicrobial activities of ethanolic extracts of Chinese quince (Pseudocydonia sinensis) pomace. In Bangladesh Research Publication Journal, vol. 11, p. 175-181.

KHOSHBAKHT, K., HAMMER, K. 2006. Savadkouh (Iran) - an evolutionary centre for fruit trees and shrubs. In Genetic Resources and Crop Evolution, vol. 53, p. 641-651. http://dx.doi.org/10.1007/ s10722-005-7467-8

KILIC, Ö. 2018. Essential oil and fatty acid composition of leaves of some Lamiaceae taxa from Turkey. In Journal of Essential Oil Bearing Plants, vol. 21(6), p. 1706-1711. http://dx.doi. org/10.1080/0972060x.2018.1538820

KIM, C.S., KWON, O.W., KIM, S.Y., UN CHOI, S.U., KIM, K.H., LE, K.R. 2014. Five New Oxylipins from Chaenomeles sinensis. In Lipids, vol. 49, p. 1151-1159. https://doi.org/10.1007/ s11745-014-3953-0 
KLYMENKO, S., GRYGORIEVA, O., BRINDZA, J. 2017. Less Known Species of Fruit Crops. Slovak University of Agriculture in Nitra. http://dx.doi.org/10.15414/2017.fe-9788055217659

KOIWAI, A., SUZUKI, F., MATSUZAKI, T., \& KAWASHIMA, N. 1983. The fatty acid composition of seeds and leaves of Nicotiana species. In Phytochemistry, vol. 22(6), p. 1409-1412. http://dx.doi. org/10.1016/s0031-9422(00)84024-8

KUMAR, A., ILAVARASAN, R., JAYACHANDRAN, T., DECARAMAN, M., ARAVINDHAN, P., PADMANABHAN, N., KRISHNAN, M.R.V. 2009. Phytochemical investigation on a tropical plant, Syzygium cumini from Kattuppalayam, Erode District, Tamil Nadu, South India. In Pakistan Journal of Nutrition, vol. 8(1), p. 83-85. http://dx.doi.org/10.3923/pjn.2009.83.85

LEWKO, J., ŠCIBISZ, K., SADOWSKI, A. 2004. Mineral element content in the leaves of rootstocks used for pears and of maiden trees budded on them. In Acta Sci. Pol., Hortorum Cultus, vol. 3(2), p. 147-152.

LI, Y., LI, Y., YANG, P., ZHANG, H., HE, D. 2017. Phospholipid and fatty acid composition in leaves and roots of ten autumn chrysanthemum cultivars grown at low temperature. In Horticulture, Environment, and Biotechnology, vol. 58(4), p. 334-341. http://dx.doi.org/10.1007/s13580-017-0227-9

LIM, T.K. 2012. Pseudocydonia sinensis. In: Edible Medicinal And Non-Medicinal Plants. Springer, Dordrecht, vol. 4, p. 515-522. https://doi.org/10.1007/978-94-007-4053-2 59

LIPA, T. 2013. Changes in chemical composition of leaves and shoots during vegetation of apple-tree rootstocks in mother plantation. In Electronic Journal of Polish Agricultural Universities, vol. 16(2), \#08. Available at: http://www.ejpau.media.pl/volume16/issue2/art-08.html

LIU, X., HUANG, B. 2004. Changes in fatty acid composition and saturation in leaves and roots of creeping bentgrass exposed to high soil temperature. In Journal American Society Horticultural Science, vol. 129(6), p. 795-801. https://doi.org/10.21273//ASHS.129.6.0795

MAGBAGBEOLA, J.A.O., ADETOSO, J.A., OWOLABI, O.A. 2010. Neglected and underutilized species (NUS): a panacea for community focused development to poverty alleviation/poverty reduction in Nigeria. In Journal of Economics and International Finance, vol. 2(10), p. 208-211.

MAL, B. 2007. Neglected and underutilized crop genetic resources for sustainable agriculture. In The Indian Journal of Plant Genetic Resources, vol. 22(1), p. 1-16.

MCGAW, L.J., JÄGER, A.K., VAN STADEN, J. 2002. Isolation of antibacterial fatty acids from Schotia brachypetala. In Fitoterapia, vol. 73(5), p. 431-433. https://doi.org/10.1016/ S0367-326X(02)00120-X

MĘCZARSKA, K., CYBORAN-MIKOŁAJCZYK, S., WŁOCH, A.,BONARSKA-KUJAWA, D., OSZMIAŃSKI, J., KLESZCZYŃSKA, H. 2017. Polyphenol content and bioactivity of saskatoon (Amelanchier alnifolia Nutt.) leaves and berries. In Acta Polonia Pharmaceutica - Drug Research, vol. 74(2), p. 660-669.

MIHARA, S., TATEBA, H., NISHIMURA, O., MACHII, Y., KISHINO, K. 1987. Volatile components of Chinese quince (Pseudocydonia sinensis Schneid). In Journal of Agricultural and Food Chemistry, vol. 35(4), p. 532-537. https://doi.org/10.1021/if00076a023

MIŠURCOVÁ, L., AMBROŽOVÁ,J., SAMEK, D. 2011. Seaweed lipids as nutraceuticals. In Advances in Food and Nutrition Research, vol. 64, p. 339-355. https://doi.org/10.1016/B978-0-12-387669-0.00027-2

MONKA, A., GRYGORIEVA, 0., CHLEBO, P., BRINDZA, J. 2014. Morphological and antioxidant characteristics of quince (Cydonia oblonga Mill.) and Chinese quince fruit (Pseudocydonia sinensis Schneid.). In Potravinarstvo, vol. 8, p. 333-340. https://doi.org/10.5219/415

MORGAN, K.T. 2008. Nutritional determinants of bone health. In J. Nutr.Elder., vol. 27, p. 3-27

NATURAL PRODUCTS RESEARCH INSTITUTE. 1998. Medicinal plants in the Republic of Korea. Western Pacific Series. No 21. Seoul National University/WHO Regional Publications, Manila, 316 p. ISBN 9290611200.

OKU, H., UEDA, Y., ISHIGURO, K. 2003. Antipruritic Effects of the Fruits of Chaenomeles sinensis. In Biological and Pharmaceutical Bulletin, vol. 26(7), p. 1031-1034. https://doi.org/10.1248/ bpb.26.1031 
OLIVEIRA, A.P., PEREIRA, J.A., ANDRADE, P.B., VALENTÃO, P., SEABRA, R.M., SILVA, BRANCA, M. 2007. Phenolic profile of Cydonia oblonga Miller leaves. In J. Agric. Food Chem., vol. 55(19), p. 7926-7930. https://doi.org/10.1021/jf0711237

OSAWA, K., MIYAZAKI, K., IMAI, H., ARAKAWA, T., YASUDA, H., TAKEYA, K. 1999. Inhibitory effects of Chinese quince (Chaenomeles sinensis) on hyaluronidase and histamine release from rat mast cells (in Japanese with English summary). In Natural Medicines, vol. 53, p. 188-193.

OSAWA, K., YASUDA, H., MORITA, H., TAKEYA, K., ITOKAWA, H. 1997. Antibacterial and antihemolytic activity of triterpenes and $\beta$-sitosterol isolated from Chinese quince (Chaenomeles sinensis). In Natural Medicines, vol. 51, p. 365-367.

PENAUELAS, J., FILELLA, I., TOGNETTIR, R. 2001. Leaf mineral concentrations of Erica arborea, Juniperus communis and Myrtus communis growing in the proximity of a natural CO2 spring. In Global Change Biology, vol. 7(3), p. 291-301. https://doi.org/10.1046/j.1365-2486.2001.00409.x

PRIETO, P., PINERA, M., AGUILAR, M. 1999. Spectrophotometric quantitation of antioxidant capacity through the formation of a phosphomolybdenum complex: Specific application to the determination of vitamin E. In Analytical Biochemistry, vol. 269, p. 334-337. https://doi.org/10.1006/ abio.1999.4019

RUBANZA, C.D.K., SHEM, M.N., BAKENGESA, S.S., ICHINOHE, T., FUJIHARA, T. 2007. The content of protein, fibre and minerals of leaves of selected Acacia species indigenous to north-western Tanzania. In Archives of Animal Nutrition, vol.61(2), p. 151-156. https://doi.org/10.1080/17450390701203907

SANCHES-MORENO, C., LARRAURI, A., SAURA-CALIXTO, F. 1998. A procedure to measure the antioxidant efficiency of polyphenols. In Journal of Sciences and Food Agricultural, vol. 76(2), p. 270-276. https://doi.org/10.1002/(SICI)1097-0010(199802)76:2<270::AID-ISFA945>3.0.CO;2-9

SAWAI, R., KURODA, K., SHIBATA, T., GOMYOU, R., OSAWA, K., SHIMIZU, K. 2008. Antiinfluenza virus activity of Chaenomeles sinensis. In Journal of Ethnopharmacology, vol. 118, p. 108-112. https:// doi.org/10.1016/i.jep.2008.03.013

SAWAI-KURODA, R., KIKUCHI, S., SHIMIZU, Y.K., SASAKI, Y., KURODA, K., TANAKA, T., YAMAMOTO, T., SAKURAI, K., SHIMIZU, K. 2013. A polyphenol-rich extract from Chaenomeles sinensis (Chinese quince) inhibits influenza A virus infection by preventing primary transcription in vitro. In Journal of Ethnopharmacology, vol. 146, p. 866-872. https://doi.org/10.1016/j.jep.2013.02.020

SEIDEL, V., TAYLOR, P.W. 2004. In vitro activity of extracts and constituents of Pelargonium against rapidly growing mycobacteria. In International Journal of Antimicrobial Agents, vol. 23(6), p. 613619. https://doi.org/10.1016/j.ijantimicag.2003.11.008

SHAHIDI, F., AMBIGAIPALAN, P. 2015. Phenolics and polyphenolics in foods, beverages and spices: antioxidant activity and health effects - a review. In J Funct Foods, vol. 18, p. 820-897. https://doi. org/10.1016/j.jff.2015.06.018

SHAHIN, L., PHAAL, S.S., VAIDYA, B.N., BROWN, J.E., JOSHEE, N. 2019. Aronia (Chokeberry): an underutilized, highly and nutraceutical plant. In Journal of Medicinally Active Plants, vol. 8(4), p. 46-63.

SHUKLA, SH., HEGDE, S., KUMAR, A., CHAUDHARY, G., TEWARI, SH.K., UPRETI, D.K., PAL, M. 2018. Fatty acid composition and antibacterial potential of Cassia tora (leaves and stem) collected from different geographic areas of India. In Journal of Food and Drug Analysis, vol. 26(1), p. 107-111. http://dx.doi.org/10.1016/j.jfda.2016.12.010

SINGLETON, V.L., ROSSI, J.A.1965.Colorimetry of total phenolics with phosphomolybdic-phosphotungstic acid reagents. In American Journal of Enology and Agricultural, vol. 6, p. 144-158.

STAHL, W., SIES, H. 2003. Antioxidant activity of carotenoids. In Molecular Aspects of Medicine, vol. 24(6), p. 345-351. https://doi.org/10.1016/S0098-2997(03)00030-X

STANKOVIC, M.S., ZIA-UL-HAQ M., BOJOVIC, B.M., TOPUZOVIC, M.D. 2014. Total phenolics, flavonoid content and antioxidant power of leaf, flower and fruits from cornelian cherry (Cornus mas L.). In Bulgarian Journal of Agricultural Science, vol. 20(2), p. 358-363. 
Grygorieva, O., Klymenko, S., Vergun, O., Shelepova, O., Vinogradova, Y., Ilinska, A., Horčinová Sedláčková, V., Brindza, J.

Agr.bio.div. Impr. Nut., Health Life Qual., 2020, 78-93

SUZUKI, H. 1994. Encyclopedia of traditional oriental drugs. Ishiyaku: Tokyo, Japan.

THEOBALD, H. 2005. Dietary calcium and health. In Nutrition Bulletin, vol. 30(3), p. 237-277. https:// doi.org/10.1111/j.1467-3010.2005.00514.x

THI, N.D., HWANG, E.-S. 2014. Bioactive compound contents and antioxidant activity in aronia (Aronia melanocarpa) leaves collected at different growth stages. In Preventive Nutrition and Food Science, vol. 19(3), p. 204-212. http://dx.doi.org/10.3746/pnf.2014.19.3.204

UNITED STATES DEPARTMENT OF AGRICULTURE. 2013. Agricultural Research Service, National Genetic ResourcesProgram.GermplasmResourcesInformationNetwork[OnlineDatabase]. [cit.2013-01-17]. Available online at: http://www.ars-grin.gov/cgi-bin/npgs/html/taxon.pl?318589

WANG, L., H.M., LIU, H.M., XIE, A.J., WANG, X.D., ZHU, C.Y., QIN, G.Y. 2018. Chinese quince (Chaenomeles sinensis) seed gum: Structural characterization. In Food Hydrocolloids, vol. 75, p. 237-245. https:// doi.org/10.1016/j.foodhyd.2017.08.001

WILLIAMS, F.H. 2008. Neuromuscular complications of nutritional defi-ciencies. In Phys. Med. Rehabil. Clin. N. Am., vol. 19, p. 125-148.

WIND, J., SMEEKENS, S., HANSON, J. 2010. Sucrose: Metabolite and signaling molecule. In Phytochemistry, vol. 71(14-15), p. 1610-1614. https://doi.org/10.1016/j.phytochem.2010.07.007

YILDIRIM, F., ŞAN, B., YILDIRIM, A.N., POLAT, M., ERCIŞLI, S. 2015. Mineral composition of leaves and fruit in some myrtle (Myrtus communis L.) genotypes. In Erwerbs-Obstbau, vol. 57, p. 149-152. https://doi.org/10.1007/s10341-015-0243-9

ZHONG, D., DU, H., WANG, ZH. 2011. Genotypic variation in fatty acid composition and unsaturation levels in Bermudagrass Associated with leaf dehydration tolerance. In J. American Society for Horticultural Science, vol. 136(1), p. 35-40. https://doi.org/10.21273/JASHS.136.1.35

ZHOU, Y., ZHAO, W., SHANG, F., ZHANG, D. 2020. Development of bioactive components from Chaenomeles sinensis leaves. In Thermal Science, vol. 24(3), p. 1795-1802. https://doi.org/10.2298/ TSCI190524066Z 